\title{
TRABALHO, EDUCAÇÃO E ENFERMAGEM: MARCO CONTEXTUAL DA FORMAÇÃO PROFISSIONAL DE NÍVEL MÉDIO EM SAÚDE ${ }^{1}$
}

\author{
Amailson Sandro de Barros \\ Faculdade Campo Real - $\mathrm{PR}^{2}$ \\ Carlos Herold Junior \\ Universidade Estadual do Centro-Oeste /UNICENTRO - $\mathrm{PR}^{3}$
}

\section{RESUMO}

Este artigo tem como eixo norteador a compreensão do processo de profissionalização da enfermagem brasileira a partir de seu entrelaçamento entre as áreas Trabalho e Educação. Como recorte histórico, o presente estudo delimitou-se as últimas décadas do século XIX e início do século XX, período de transformações urbanísticas e sanitárias essenciais ao desenvolvimento econômico brasileiro. A escolha pelo estudo da profissionalização em enfermagem deve-se a evidência de que em seu processo de divisão social do trabalho, esta categoria profissional, demonstra a diferença entre aqueles trabalhadores que exercem $o$ trabalho intelectual e aqueles que atuam no trabalho manual. Nesse processo de separação, trabalho intelectual versus trabalho manual, a educação que é destinada ao primeiro grupo prioriza conhecimentos de cunho mais administrativos e de supervisão do trabalho em enfermagem, assumindo aspectos gerenciais e determinando o trabalho do segundo grupo, cuja educação profissional se caracteriza por noções básicas acerca das técnicas de enfermagem.

Palavras-chave: Educação; Trabalho; Enfermagem.

\section{EMPLOYMENT, EDUCATION AND NURSING: CONTEXTUAL BENCHMARCK OF PROFESSIONAL TRAINING IN HEALTH CARING AT HIGH SCHOOLS}

\begin{abstract}
This article is was conceived to arouse understanding on the process of professionalization of nursing in Brazil from its relation between Laboral and Educational areas. The historical period considered to the present study focus on the final decades of the nineteenth and early twentieth century, a period of urban changes which were essential to health and economic development in Brazil. The choice for the study of professional nursing is due to the evidence that in the process of social labor division, this professional category, reveals the difference between those workers engaged in intellectual work and those who performed the manual labor. In this separation process, intellectual work versus manual labor, the education that is conveyed to the first group prioritizes knowledge mostly on administrative and supervisory work in nursing, assuming managerial aspects and determining the work of the second group, whose professional education is carried out on the basics of nursing techniques.
\end{abstract}

Keywords: Education; Labor; Nursing. 


\section{A trajetória da formação profissional em enfermagem no Brasil}

$\mathrm{Na}$ tentativa de desenvolver um estudo de natureza histórica do surgimento da enfermagem profissional no Brasil, partiu-se de uma breve discussão das mudanças estruturais que ocorreram no contexto brasileiro, a partir do último quartel do século XIX e início do século XX, culminando com a Revolução de 1930, ressaltando, nesse recorte temporal, os aspectos essenciais para a compreensão do objeto de estudo.

Nesse período histórico, conforme ressaltam Rizzotto (1999) e Saviani (2006), a sociedade brasileira foi marcada por alguns acontecimentos que contribuíram para a transformação política, econômica, social e cultural do Brasil. Entre esses acontecimentos, os autores destacam, como os mais significativos, a abolição da escravatura (1888), a Proclamação da República (1889), a Primeira Guerra Mundial (1914-1918), a Revolução de 1930, a crise do ciclo cafeeiro, a aceleração do processo industrial, o incremento da imigração, a urbanização, os movimentos sociais e a Semana de Arte Moderna (1922). O País, durante esse período, era governado pelas oligarquias formadas pelos Estados de São Paulo, Rio de Janeiro e Minas Gerais. A cafeicultura era o principal setor da economia e os fazendeiros do café formavam o grupo dominante, a aristocracia do café, o que lhes assegurava grande poder político e econômico na esfera do governo federal.

Segundo Rizzotto (1999), as transformações no cenário brasileiro, durante o século XIX, de modo específico a partir da expansão e declínio do cultivo do café, geraram sucessivas rearticulações internas e externas, para que o País pudesse se adequar ao sistema mundial, que começava a impor limitações e reduções no volume das importações de produtos primários produzidos e comercializados pelo Brasil, principalmente o café. Para a autora, uma das consequências da diminuição na quantidade de exportação de café brasileiro para outros países deu-se pela "diminuição do consumo nos mercados externos e da concorrência de outros centros produtores" (idem, p.13).

De outro lado, foi intenso o processo imigratório, no Brasil, no final do século XIX e início de século XX, principalmente nos Estados do Rio de Janeiro e São Paulo. Rizzotto (1999) estima que, nesse período, cerca de 4,5 milhões de pessoas, entre italianos, portugueses e espanhóis vieram para o Brasil, com o intuito inicial de trabalhar na agricultura. Porém, devido às crises no setor agrícola, deslocaram-se para os centros urbanos, em busca de trabalho nas fábricas. O resultado desse deslocamento foi uma aglomeração de pessoas em precárias condições de vida, o que agravava os problemas de saúde entre a população.

Bertolli Filho (2008, p.16), ao discutir a influência do período das oligarquias para a saúde pública brasileira, mostra que, durante esse período, os governos buscaram apoio na "ciência da higiene para examinar detidamente o ambiente físico e social das populações urbanas" e, a partir dela, definir "estratégias para melhorar as condições sanitárias das áreas vitais para a economia nacional - as cidades e os portos." O combate às epidemias tornou-se, portanto, prioridade política e sanitária, combatida predominantemente pelo higienismo e pelos princípios da corrente bacteriológica e da eugenia. De acordo com Marques (1994, p.27), a eugenia "vinha assim qualificar a higiene como impositora de normas para regular a vida social das populações urbanas, ampliando consideravelmente aquele campo de atuação."

Nesse cenário, o discurso médico estabelece sua hegemonia no campo da saúde e uma relação de superioridade com as demais profissões que atuam nesse campo, em especial a enfermagem, que dava seus primeiros passos para a profissionalização de sua prática, em muito orientada pela ordem médica. 
Segundo Germano (1993), Pires (1998), Moreira e Oguisso (2005) e Ribeiro (2009), a primeira escola de enfermagem no Brasil surge em 1890, junto ao Hospício Nacional de Alienados, no Rio de Janeiro, com a proposta de formar mão de obra para substituir as irmãs de caridade, que haviam sido dispensadas do trabalho no hospício, por motivos de desentendimentos ideológicos com a direção geral da instituição, que era ocupada por médicos. O problema surgiu tendo em vista que elas não seguiam as ordens dos médicos-diretores, atendendo os doentes à sua maneira, acobertando, inclusive, os maus tratos dos "enfermeiros" contra os doentes mentais.

De acordo com os autores, a falta de pessoal capacitado para substituir as irmãs de caridade no trabalho com os doentes mentais fez com que o governo provisório da República aprovasse o Decreto ${ }^{\circ}$. 791/1890, criando a Escola Profissional de Enfermeiros e Enfermeiras, posteriormente conhecida e oficializada em 1942, no governo de Getúlio Vargas, como Escola de Enfermagem Alfredo Pinto.

Organizada e dirigida pelos médicos, as regras que determinavam a profissionalização e exercício da prática de enfermagem, na Escola, que funcionava no interior do Hospital, pautaram-se no modelo francês de atendimento aos doentes e de educação das alunas. Por este modelo, privilegiavam-se os estudos clínicos fortemente vinculados às práticas médicas, pautados nas novas noções de assepsia e de higiene no trabalho hospitalar. Inicialmente propostas à medicina francesa do século XIX por Pasteur, essas noções preconizavam um ambiente limpo e organizado, como forma de evitar o contágio de doenças por micróbios entre pacientes e trabalhadores. Como resultado, os procedimentos no cuidado com o doente e com a organização do ambiente hospitalar passaram por alterações. O caráter assistencialista de atendimento, aos poucos, foi sendo substituído por um atendimento pautado no saber médico. Essas alterações representaram, também, "um desafio ao poder absoluto exercido pelas religiosas no cuidado dos doentes" (Oguisso, 2007, p.131).

As descobertas de Pasteur impulsionaram a valorização do conhecimento científico e preconizaram a laicização dos hospitais, ocasionando uma ruptura da medicina com a enfermagem empírica, exercida pelas religiosas e, em alguns casos, por pessoas que não tinham preparo algum e que apenas recebiam uma mísera gratificação pelos seus serviços. Entre essas pessoas, estavam mulheres que não serviam para a indústria, por serem consideradas imorais e analfabetas (JAMIESON, 1966 apud SOBOLL, 2003).

Para romper com tal situação, o esforço empreendido deu-se pela escolarização da enfermagem, que passou a ser de responsabilidade dos médicos. Foram eles que elaboraram os primeiros manuais de enfermagem e eram eles que preparavam tecnicamente as enfermeiras, para que elas atuassem exclusivamente como suas auxiliares (OGUISSO, 2007), ao mesmo tempo em que consolidavam "o saber e o poder médico no interior das instituições" (MOREIRA e OGUISSO 2005, p.99).

O hospital tornara-se um santuário, e mais ainda a sala de cirurgia, onde a assepsia era um rito sagrado, um verdadeiro cerimonial. Relata-nos Maria da Conceição Souza. Se os médicos, autores dos manuais, insistiam na submissão absoluta e definitiva das enfermeiras, era porque eles tinham medo de correr o risco de deixá-las agir com técnicas um pouco mais elaboradas. A enfermeira deveria secundar o médico, mas nunca substituí-lo; e o melhor modo de evitar isso era limitar sua instrução às coisas de seu mister. Pura e simples executora de ordens, toda iniciativa lhe era interditada, e apenas o seu valor moral era colocado em primeiro 
plano, como se fosse uma "religiosa leiga" (MOREIRA e OGUISSO, 2005, p.72-73).

Dessa maneira, os médicos tornavam-se os detentores do conhecimento formal sobre a saúde e a doença, enquanto que a enfermagem se organizava e desenvolvia suas ações subordinada ao gerenciamento médico (PIRES, 1998).

A partir de então, outras escolas foram criadas: Escola de Enfermeiras do Hospital Samaritano, em São Paulo, em 1896, instituição privada; Escola de Enfermagem da Cruz Vermelha, em 1916; e cursos de Enfermagem nos hospitais militares, em 1921 (GERMANO, 1993; RIZZOTTO, 1999; OGUISSO, 2007).

Foi apenas em 1923, com a criação da Escola de Enfermeiras do Departamento Nacional de Saúde Pública - aprovada pelo Decreto $n^{\circ} 16.300 / 23$ - atual Escola de Enfermagem Anna Nery, que o ensino brasileiro de enfermagem, seguindo o modelo norteamericano, introduzido no Brasil pela Fundação Rockefeller passou a ser organizado e ministrado exclusivamente por enfermeiras: "Daí por que a maioria dos documentos registra-a como a primeira escola de enfermagem do país" (GERMANO, 1993, p.27). Tão logo formadas, as enfermeiras passam a ser as responsáveis diretas "por formar pessoal auxiliar para o exercício das tarefas delegadas de cunho predominantemente manual" (PIRES, 1998,p.93). Destaca-se que, em seus primórdios, a formação de enfermeiras pela Escola Anna Nery foi organizada seguindo os princípios nightingalianos: "dar formação técnica específica, com ensino metódico por enfermeiras e não ocasional, por meio da prática", mantendo um alto padrão de seleção e ensino, sendo as primeiras alunas recrutadas e pertencentes à classe média e média alta (OGUISSO, 2007, p.83).

Ademais, as condições para ingresso na escola demonstravam certo elitismo e preconceito. Exigia-se das candidatas o diploma de Escola Normal ou equivalente, o que "por si só, já restringia o acesso a uma determinada classe", se considerado que naquele período não era comum as mulheres pobres irem além da alfabetização (RIZZOTTO, 1999, p.24), bem como, priorizava-se, na admissão, mulheres brancas (GERMANO, 1993). Essas medidas buscavam imprimir uma nova ideologia ao trabalho de enfermagem e, com isso, criar uma nova identidade profissional, que se consubstanciava em exigências comportamentais e morais, referentes aos trajes e à postura corporal das alunas (OGUISSO, 2007); porém, sem romper, nas relações de trabalho, com a hegemonia médica masculina e a submissão feminina.

Vale ressaltar que o estereótipo de enfermeira retratava uma mulher bondosa, carinhosa, caridosa, obediente e servil, características que passaram a ser exploradas no trabalho institucionalizado da enfermagem e que reportavam aos aspectos sociais do papel da mulher (esposa, mãe), almejados pelos homens (pais, esposo, médico) e também aos valores religiosos que se associam a sua história. Estendia-se, assim, o caráter patriarcal de subordinação feminina da esfera privada/doméstica para a esfera pública/profissional. A enfermagem institucionalizou-se, portanto, como uma profissão eminentemente feminina, pois suas atividades profissionais se aproximavam daquelas realizadas pelas mulheres em seu ambiente familiar, no cuidado das necessidades básicas das crianças, dos velhos e dos doentes e na organização e limpeza do lar (WAINBERG, 2004; LOPES e LEAL, 2005).

Referente à divisão do trabalho dentro da enfermagem, a partir da questão de gênero, Oguisso (2007, p.153) apoiado em Possollo (1920), demonstra que, historicamente, os homens também já exerciam a ação de cuidar e que a preferência deles se voltava "para cuidar dos loucos (homens) ou, então, eram mais afeitos aos serviços de saúde na guerra e nas linhas de frente ou ainda nos navios de combate". A autora relata que Florence 
Nightingale defendia a preferência por mulheres na profissão, pois acreditava que os enfermeiros, mesmo sendo "bondosos", não tinham condições de suprir todas as necessidades da enfermagem e dos pacientes. Para Florence, segundo Oguisso (2007), "as enfermeiras saberiam tomar melhor as decisões sobre como cuidar de pacientes" (idem), pois Nightingale corroborava com a ideia dominante de que as mulheres eram mais predispostas ao cuidado e atenção à saúde.

Wainberg (2004) também observou que, historicamente, a inserção de profissionais de enfermagem do sexo masculino nos hospitais se destina a realização de tarefas em áreas que exigem força física, tais como psiquiatria, tratamento intensivo, emergência, ortopedia e traumatologia.

O processo de feminilização da enfermagem pode ser observado com maior ênfase no Brasil após a criação da Escola Anna Nery (WAINBERG, 2004; OGUISSO, 2007), uma vez que a pretensão inicial da escola era formar "enfermeiras visitadoras", com o objetivo de atuar como educadoras sanitárias, que ensinariam aos moradores dos bairros carentes noções básicas de higiene; porém, isso não ocorreu. Uma das razões que contribuiu para essa não realização, segundo Rizzotto (1999), estava na forma como foi elaborado o programa de ensino proposto pela escola, que enfatizava o atendimento individual e curativo, muito mais voltado ao contexto hospitalar, do que ao atendimento coletivo e preventivo.

Neste período, as doenças faziam várias vítimas, principalmente em regiões portuárias, o que representava sérios problemas mercantis para o Brasil. A falta de infraestrutura e de saneamento básico, nesses locais, favorecia o surgimento e proliferação de doenças contagiosas, como a cólera, febre amarela, sarampo, varíola, lepra, tuberculose, entre outras, tornando-se um grave problema a ser combatido pelas autoridades políticas (DECCA, 1991; GERMANO, 1993; RIZZOTTO, 1999), pois

[...] eram constantes as advertências externas, por parte dos países que comercializavam com o Brasil, em parar com as negociações, caso persistissem as constantes epidemias e endemias que representavam uma ameaça aos tripulantes dos navios que aqui aportavam, bem como à população de seus países de origem, sem contar com a necessidade que tinha o Brasil de atrair mão de obra fundamental para a constituição do mercado de trabalho capitalista (GERMANO, 1993, p.34).

Portanto, muito mais do que atender às necessidades de uma população doente, os serviços de controle de doenças e as medidas de saneamento visavam os interesses do capital em atrair para os espaços urbanos mão de obra para o processo de industrialização. É importante destacar que, no plano socioeconômico e político, o Brasil de meados do século XX passava a enfrentar a crise do capitalismo internacional que se refletia na economia brasileira, elevando o custo de vida, acentuando o desemprego e reduzindo os salários e as conquistas sociais dos trabalhadores (RIZZOTTO, 1999).

Essa situação favoreceu a ampliação das lutas reivindicatórias pelos movimentos sociais que, inconformados com os encaminhamentos das questões políticas, sociais e econômicas do país, organizavam greves, dentre as quais destacamos a Greve Geral de 1917, que se tornou símbolo da intensa agitação social contra as condições subhumanas a que estavam expostos os trabalhadores e suas famílias (DECCA, 1991; MARQUES, 1994 e RIZZOTTO, 1999). Decca (1991) demonstra que o cotidiano dos trabalhadores urbanos, dentro e fora das fábricas, era árduo e penoso. As jornadas de trabalho se estendiam até 
13,14 e mesmo 15 horas e, inclusive, as crianças eram expostas a períodos longos de trabalho.

No período em que estamos tratando, os trabalhadores assalariados se constituíam, principalmente, de imigrantes europeus atraídos pelo surto industrial e que formavam uma força de trabalho quantitativa e qualitativamente diferente, que veiculava novas ideologias, "contaminando" o conjunto da classe trabalhadora brasileira. As epidemias, a falta de segurança no trabalho, as péssimas condições de vida e a falta de assistência à saúde acabaram levando os trabalhadores, agora mais organizados, a explicitar com mais clareza os antagonismos da relação capital versus trabalho. Determinadas bandeiras liberais, que tinham sido assumidas como discurso pelos republicanos, foram reivindicadas pelos trabalhadores, como direitos de cidadania, estimulando lutas sociais que assumiram papel relevante no período de 1910/1920. (RIZZOTTO, 1999, p.19).

Nesse contexto, como afirma Rizzotto (1999, p.20), o Estado Brasileiro cumpre a sua vinculação aos interesses burgueses, oferecendo determinados serviços de saúde e de educação com "o objetivo de atenuar e/ou desviar a atenção dos conflitos gerados pelo próprio modo de produção. Negava-se a cidadania pelo assistencialismo", como forma de manter o controle das contradições sociais, pois:

Nessa relação, como se sabe, as forças são desiguais; ao trabalhador não retorna o produto de seu trabalho e, muitas vezes, nem mesmo o indispensável para sua sobrevivência e de sua família. Isso resulta num empobrecimento progressivo, que os empurra para os locais mais insalubres, onde ficam suscetíveis, pelas próprias condições de vida, às mais diferentes doenças orgânicas e do meio (RIZZOTTO, 1999. P.19).

Bertolli Filho (2008) lembra que as condições de higiene e saúde nos bairros operários eram inexistentes. As casas eram construídas desordenadamente, sem esgoto e água encanada, consideradas inadequadas e insuficientes para a habitação dos trabalhadores, o que aumentava o risco de contaminação e de mortalidade por diversas doenças infectocontagiosas, representando uma "chaga oculta no coração da cidade" (DECCA, 1991, p.48). Frente a essa situação, os poderes públicos municipais, estaduais e federais

[...] passaram a recomendar, desde a primeira década do século XX, a construção de vilas higiênicas e baratas para o operariado, incentivando a iniciativa privada de várias formas. No entanto, nas grandes cidades ou capitais dos estados brasileiros, a construção de moradias populares foi se tornando um grande negócio e não implicou melhoria do padrão habitacional para a grande massa de trabalhadores urbanos e industriais (DECCA, 1991, p.49-50).

Entretanto, as transformações urbanísticas e sanitárias adotadas pelo governo e pela iniciativa privada favoreciam os bairros onde moravam as elites econômicas e as áreas onde se centralizavam a indústria e comércio, as quais receberam esgotos, serviços de luz elétrica e água potável. Com isso, garantiam-se condições "minimamente saudáveis para a estabilidade e eficiência das atividades produtivas. As camadas mais pobres da população, 
ao contrário, continuavam a ter precárias condições de vida" (BERTOLLI FILHO, 2008, p.26).

A este respeito, Decca (1991) traça o seguinte perfil:

\begin{abstract}
Alguns grandes industriais construíram vilas operárias junto às suas fábricas, mas cobravam aluguéis elevados. Nas grandes cidades, eram raras as indústrias que construíam moradias vantajosas para o operariado empregado; em geral, quando essas moradias ou vilas operárias eram construídas, destinavam-se aos operários especializados, que era necessário reter e controlar junto à produção. Vilas operárias que apresentavam condições adequadas e aluguel relativamente barato eram frequentes no interior dos estados, em núcleos distantes, onde era preciso fixar a mão de obra. (DECCA, 1991, p.51).
\end{abstract}

As epidemias, que não eram novidades, já recebiam as preocupações do governo através de alguns institutos criados no final do século XIX, como o Conselho de Saúde Pública (1890), Laboratório Bacteriológico, Vacinogênico e de Análise Clínicas e Farmacêutica (1892), Instituto Sanitário Federal (1894), Diretoria Geral de Saúde Pública (1897) e Instituto Pasteur (1903) que, articulados ao Serviço Sanitário, buscavam assegurar a eficiência dos trabalhos dos higienistas e dos fiscais sanitários. As práticas sanitárias realizadas pelos serviços públicos se concentravam na desordem urbana, no combate às doenças, no desregramento moral, na higiene e no controle de hábitos da sociedade sem, entretanto, demonstrar uma preocupação com políticas públicas que realmente se concretizassem numa melhora de vida da população (RIZZOTTO,1999; BERTOLLI FILHO, 2008):

No Brasil, a concepção "campanhista/policial" vigorou até a segunda década deste século. Porém outras experiências começaram a surgir, cuja ênfase não era unicamente nas campanhas e no saneamento, mas em serviços ambulatoriais permanentes de combate a determinadas doenças. Essa tentativa de mudança na implementação de determinadas práticas sanitárias foi a resposta dada pelos sanitaristas brasileiros, assessorados por entidades norte-americanas, como a Fundação Rockfeller, à crise sanitária presente no início dos anos vinte. Essa crise, percebia-se que não tinha como causa principal as epidemias, mas ao processo de pauperização da população urbana, acentuada pelas oscilações na economia cafeeira e pelo conflito mundial de 1914 a 1918 (RIZZOTTO, 1999, p.18).

A partir da década de 1930, chega ao fim a hegemonia política formada pela classe dominante ligada à exportação de café. Inicia-se o governo Vargas e, com ele, uma ampla reforma administrativa e política, que visava centralizar a máquina governamental e também bloquear as reivindicações sociais. No campo da saúde, o governo Vargas reestruturou e dinamizou o Departamento Nacional de Saúde Pública (DNSP), incorporando-o ao recém criado Ministério da Educação e da Saúde. Com a criação do Ministério da Educação e da Saúde, o compromisso do Estado com a saúde pública deslocou definitivamente o foco de atendimento preventivo e coletivo para o atendimento curativo individual e hospitalocêntrico.

Em 1937, o centralismo e a autoridade presidencial de Vargas passaram a ser reforçados pela nova constituição que, elaborada nos modelos constitucionais da Polônia, 
Alemanha, Itália e Portugal, centralizou todos os poderes executivos, legislativos e judiciários na pessoa do chefe de Estado, visto como tutor da sociedade (BERTOLLI FILHO, 2008).

O governo populista de Vargas apresentava o Estado como o pai da sociedade e Getúlio como o pai dos pobres, que provinha o que julgava necessário ao cidadão. A relação de compromisso do Estado com a saúde passou a ter um novo foco, o de assistir o necessitado até que ele recuperasse a saúde e assim restaurasse sua capacidade produtiva. Nesse sentido, zelava-se pelo seu bem-estar sanitário e assistência médico-hospitalar (BERTOLLI FILHO, 2008).

A política de saúde na Era Vargas, com forte tendência ao atendimento individualizado, criou uma demanda crescente pelo serviço médico hospitalar, o que foi garantido, principalmente, pelas Caixas de Aposentadoria e Pensões e os Institutos de Previdência (RIBEIRO, 2009).

Nesse cenário, que defendia o modelo hospitalocêntrico como referência de assistência à saúde, o trabalho das enfermeiras visitadoras mostrava-se ineficiente, sem recompensas visíveis (BARREIRA, 1993 citado por RIZZOTTO, 1999) e o país ainda permanecia "doente": "muitos brasileiros enfermos continuavam a morrer sem receber a ajuda médica necessária" (BERTOLLI FILHO, 2008, p.38), o que resultava em uma demanda crescente para os serviços hospitalares individualizados.

Entretanto, conforme Bertolli Filho (2008), os movimentos sociais começaram a questionar a ordem vigente e a exigir um serviço de saúde mais eficiente para a maioria da população, pressionando o governo a melhorar a saúde do povo. Por outro lado, o atendimento à saúde voltado para a hospitalização criava ofertas de trabalhos em enfermagem que ultrapassavam o número de profissionais disponíveis no mercado.

É, também, na década de 1930, que a prática do exercício profissional de enfermagem teve sua regulamentação, através do Decreto $\mathrm{n}^{\circ}$ 20.109/1931, aprovado e assinado pelo presidente Getúlio Vargas. Esse mesmo decreto reconhecia a Escola Anna Nery como escola modelo de ensino em enfermagem no País. Deste então, todas as escolas de enfermagem deveriam ter seu ensino dirigido por enfermeiras diplomadas para, assim, obterem reconhecimento na formação de enfermeiras igualmente diplomadas (GERMANO,1993; RIZZOTTO, 1999). Com a aprovação desse decreto, as alunas egressas da Escola Anna Nery passaram a ser solicitadas para organizar e gerenciar os serviços, bem como o ensino de enfermagem em vários estados do Brasil. Em 1937, a escola foi incorporada à Universidade do Brasil, em forma de caráter complementar em relação à medicina, vindo a pertencer definitivamente à Universidade do Brasil no ano de 1946, através do Decreto n 21.321 (RIBEIRO, 2009).

Em contrapartida, nas décadas seguintes, o setor privado, diante da "democratização" da saúde e expansão de hospitais públicos, passou a pressionar o Estado para não competir com a medicina privada, estabelecendo acordos que trouxeram benefícios ao próprio setor, que via na prevenção e promoção da saúde grandes possibilidades de lucros. O Estado, neste momento, realizou empréstimos a juros baixos e doações à rede privada, impulsionando seu crescimento, dada a modernização dos equipamentos e dos materiais médicos. A rede privada de saúde tornava-se aquela que venderia seus serviços à população, aos institutos de aposentadoria e pensões e ao próprio governo (BERTOLLI FILHO, 2008):

Mais uma vez, o setor político interveio nos debates, aprovando leis que garantiam privilégios para os grupos privados prestadores de serviços 
médico-hospitalares. Muitas verbas oficiais destinadas a essa área iam para deputados que também eram sócios de clínicas e hospitais. Eram eles, bem mais do que a população, os beneficiados pelas verbas públicas (BERTOLLI FILHO, 2008, p.44).

A consolidação do modelo hospitalocêntrico de atendimento à saúde levou a carência de profissionais para atuar no trabalho de enfermagem. Como alternativa para a solução dessa problemática foram criados, na década de 40, pela Lei $n^{\circ} 775 / 49$, os primeiros cursos de auxiliares de enfermagem, de orientação clínico-hospitalar, com duração de 18 meses, sendo requisito para o seu ingresso que a candidata ou o candidato comprovasse a conclusão do curso ginasial (GERMANO, 1993). Stutz (2009) observa que a referida lei trazia em si a dicotomia entre o saber e o fazer na área de enfermagem, pois os cursos de auxiliares proporcionavam, na opinião da autora, apenas o adestramento de pessoal para atuar na assistência curativa, sob a supervisão do enfermeiro.

Segundo Mioto,

\begin{abstract}
Através desta Lei, "recria-se" o que Florence Nightingale estabeleceu nos primórdios da profissionalização da Enfermagem, quando estabelecia funções e atribuições diferentes para as duas categorias: às lady-nurses ou enfermeiras, destinadas às tarefas de supervisão, ensino e difusão do conhecimento; e as nurses ou auxiliares, para quem era atribuído o contato direto com o paciente, nas práticas de higiene e pequenos procedimentos (MIOTO, 2004, p.48).
\end{abstract}

Essa medida trouxe para a enfermagem a divisão de seu processo de trabalho e atendia às necessidades dos hospitais públicos e privados, vindo também, na época, ao encontro da escolaridade da maioria das mulheres brasileiras. A partir dessa lei, concretizou-se, ainda mais, para a área da enfermagem, a divisão social e técnica do trabalho. As enfermeiras passaram a executar o cuidado indireto aos pacientes, através de ações administrativas, supervisão e educação, pois caberia às auxiliares executar a maioria das atividades de assistência no cuidado direto, numa clara divisão entre trabalho intelectual e trabalho manual (RIBEIRO, 2009).

Ao se reproduzir nessas bases, a enfermagem foi se organizando e determinando a evolução de suas categorias, tal como observou Braverman (1987), ao abordar a evolução da divisão do trabalho no capitalismo, qual seja, "o modo capitalista de produção destrói sistematicamente todas as perícias à sua volta e dá nascimento a qualificações e ocupações que correspondem às suas necessidades" (BRAVERMAN, 1987, p.79).

Nesse sentido, mesmo com a atuação e legalização do exercício da enfermagem já sendo exercida pelos enfermeiros e auxiliares, ainda assim o mercado de trabalho sentia a necessidade de profissionais que fossem mais habilitados que os auxiliares para atuar no auxílio aos enfermeiros, principalmente em atividades de assistência à pacientes em estado grave e em ações de alto risco. Para solucionar a demanda por este novo profissional, mais uma categoria foi criada: o técnico de enfermagem.

\title{
A criação dos cursos Técnicos de Enfermagem de nível médio
}

Nascida na consolidação do capitalismo, a enfermagem moderna reconhece a utilidade social e insere no seu processo de trabalho a repartição de tarefas e, caracterizando a divisão social do trabalho, 
apresenta-se em dois estratos sociais distintos (PEREIRA e RAMOS, 2006, p.23).

Embora os ditames políticos e econômicos do Brasil, na década de 1960, e nos primeiros anos da década de 1970, defendessem que o País estava em um ritmo acelerado de desenvolvimento, os problemas gerados pela falta de saneamento básico e atenção à saúde coletiva eram visíveis e contribuíam para o aumento de doenças que rapidamente se transformavam em epidemias, como a dengue, a meningite e a malária. Essa situação se agravou, segundo Bertolli Filho (2008), com o período da ditadura militar dos anos sessenta que, através da censura, proibia que os meios de comunicação divulgassem essas epidemias, trazendo prejuízos à população.

As verbas do governo federal destinadas à saúde pública e ao saneamento básico eram escassas. Em sua grande parte, eram destinadas ao pagamento de serviços privados prestados aos pobres e desvalidos em hospitais particulares, contratados pelo Estado. Outra parte era destinada a campanhas de vacinação. Com essa prática, o Estado legitimava a assistência individual e médico-curativa em detrimento das ações coletivas de prevenção e educação em saúde. O hospital se constituía, portanto, no lugar exclusivo da prestação de serviços médicos que, ao lado da explosão da indústria de medicamentos, principalmente as multinacionais, lucrava com a precarização das condições de vida da população (BERTOLLI FILHO, 2008). Desse modo, as forças e os interesses econômicos e políticos de grupos ligados à prestação de serviços médicos se sobressaiam às necessidades públicas de saúde, bem como revelavam a acumulação de capital privado por intermédio de recursos públicos. Neste período, mudanças também ocorriam na área de Educação.

Em 1961, por exemplo, foi aprovada e publicada a primeira Lei de Diretrizes e Bases da Educação Brasileira (LDB), sob nº 4.024 que, não menos influenciada pelas lutas históricas de classes sociais antagônicas, propôs a equivalência e a "articulação completa entre o ramo secundário de $2^{\circ}$ ciclo e profissional, para fins de acesso ao ensino superior" (KUENZER, 2007a, p.15). Porém, a superação da dualidade estrutural do ensino não foi alcançada.

No que se refere ao ensino profissional, em seu artigo de $n^{\circ} 47$, a LDB/61 direcionava-o para as áreas industrial, agrícola e comercial. Porém, possibilitava que outros cursos técnicos, não especificados em seu caput, fossem organizados e regulamentados pelos diferentes sistemas de ensino. Essa prerrogativa garantiu que, em 1966, através dos pareceres do Conselho de Educação, sob os números 171 e 224, fossem criados os primeiros cursos técnicos de enfermagem nas Escolas Anna Nery e Luíza de Marillac (COSTA e KURCGANT, 2004), atendendo, assim, "reivindicações antigas de alguns enfermeiros, que viam a necessidade de mais um elemento na categoria profissional, em nível de $2^{\circ}$ grau, para o desempenho de tarefas com certo grau de complexidade" (COSTA, 2003).

Dessa forma, a partir da década de 1960, quatro categorias profissionais passaram a integrar os serviços de enfermagem: enfermagem de nível superior (reconhecida em 1962), técnico de enfermagem, auxiliar de enfermagem e a de atendentes (categoria formada pelos profissionais que atuavam sem possuir qualquer nível de qualificação profissional) (PEREIRA e RAMOS, 2006). De acordo com Pereira e Ramos (2006), a ideia de formar trabalhadores em nível técnico tinha, também, como objetivo, naquele momento, suprir a falta de médicos e profissionais de enfermagem de nível superior em determinadas regiões do país: 
Preparar os trabalhadores de nível médio e elementar da saúde para suprir a falta de profissionais de nível superior, no nosso entendimento, é um projeto que não contribui, efetivamente, para a melhoria nas condições de assistência à população. É diferente de um projeto que valorize e qualifique os trabalhadores de nível médio e fundamental da saúde para atuarem nas equipes de saúde, mediante a premissa de que as tarefas que por eles serão executadas exigem um saber diferenciado do saber médico, quer na prevenção, quer na assistência realizada pelos serviços de saúde (PEREIRA e RAMOS, 2006, p.34).

Para Ribeiro (2009), a institucionalização de uma nova categoria profissional, sem alterar o que já se praticava, corresponde à tendência crescente da fragmentação e aprofundamento da divisão técnica do trabalho em saúde, cuja empreitada encontra na educação um instrumental muito usado pelo sistema econômico para essa concretização.

Em 1971, auge do "milagre econômico" e vigência do governo militar, a educação brasileira passou a ser regida pela LDB n 5.692 que, sob a inspiração da "Teoria do Capital Humano", preconizada por Schultz, entendia que o ensino de nível médio deveria se preocupar como a qualificação exclusiva para o mercado de trabalho. O ensino profissionalizante tornou-se obrigatório em todas as escolas e adquiriu caráter de terminalidade, com um viés tecnicista (KUENZER, 2007a), em detrimento da formação mais teórica científica. A preocupação da LDB/71, com a oferta de ensino profissionalizante a todos os brasileiros, refletia uma proposta velada do sistema educacional em diminuir a procura pelo ensino superior para, assim, garantir maior racionalidade e desenvolvimento individual do cidadão, pela profissionalização de segundo grau. Porém, isso não foi o suficiente para diminuir a demanda pelo ingresso nas universidades. Os egressos das escolas profissionais de nível médio continuavam almejando o ensino superior, mesmo quando já estavam compondo a força de trabalho (ROMANELLI, 2002).

Todavia, devido à precariedade estrutural das escolas, não foi possível oferecer um ensino de qualidade aos alunos, que não receberam nem um ensino propedêutico nem um ensino profissional que atendesse realmente as demandas do modo de produção capitalista (KUENZER,1991). Porém, lembrando Frigotto (2006), a "improdutividade da escola" mostrou-se altamente "produtiva" ao criar um exército de reserva para os diversos setores de produção. A profissionalização estreita oportunizada na escola era improdutiva por não oferecer ao homem a (re)apropriação do domínio total do trabalho, limitando-se ao treinamento e à adaptação profissional para a produção, semiqualificando os alunos para ocupar determinados postos de trabalho, rigidamente separados entre planejamento e execução.

Quatro anos depois, acompanhando o fim do "milagre econômico", a obrigatoriedade da qualificação profissional foi extinta, com o Parecer 76/75 do Conselho Federal de Educação e o ensino de $2^{\circ}$ grau (atual Ensino Médio) passou a ter como preocupação uma formação que integrasse educação e trabalho, buscando reafirmar a complementaridade entre educação geral e formação especial. Porém, esse caráter unitário não ocorreu e a dualidade estrutural do ensino de $2^{\circ}$ grau ressurgiu:

As escolas que atendiam às classes média e burguesa reassumem sua função propedêutica, continuando a preparar os alunos para o ingresso na universidade. As escolas públicas estatais, que atendem as classes média, baixa e trabalhadora, não tendo condições mínimas para oferecer 
habilitação profissional demandada por sua clientela, em virtude da precariedade de seus recursos financeiros, materiais e humanos, fazem um arremedo de profissionalização, não dando conta da formação geral e tão pouco da formação profissional (KUENZER, 1991, p.12-13).

Sem a possibilidade de preparar, adequadamente, o aluno para o mundo do trabalho, extinguiu-se, em nível formal, no ano de 1982 , por meio da Lei $\mathrm{n}^{\circ} 7.044$, o ensino unicamente profissionalizante das escolas. $\mathrm{O}$ ensino propedêutico tornou-se predominante e desvinculado de uma educação para o trabalho. Porém, como a Lei $n^{\circ} 5.692 / 71$ e seus decretos não foram revogados, continuaram a coexistir, na prática, diversas possibilidades de formação, da geral à profissional, "passando por todas as formas intermediárias, cabendo a opção a cada escola" (KUENZER; 1991 p.13).

Outro aspecto relevante na Lei $\mathrm{n}^{\circ} 5.692 / 71$ foi que, em seu capítulo IV, ela assegurava o ensino supletivo, oportunizando escolarização regular e educação profissional para adolescentes e adultos que não tinham concluído os anos escolares em idade própria e, portanto, estavam à margem do sistema formal de educação (BRASIL, 1971). No caso da enfermagem, cita-se os atendentes de enfermagem, que exerciam suas funções sem possuir as devidas qualificações e certificação profissional outorgadas pela escola. A oferta de ensino supletivo, preconizada no texto da LDB/71, possibilitou que a Associação Brasileira de Enfermagem (ABEn) estabelecesse um convênio com o Ministério da Educação, via Programa Intensivo de Preparação de mão de obra e, a partir dele, organizasse cursos na rede básica de saúde, para capacitar e difundir o conhecimento específico da enfermagem para um número significativo de atendentes. Na época, 40 mil trabalhadores foram capacitados e treinados, "principalmente de nível elementar, embora tenham sido atingidos também profissionais de nível médio e superior" (GERMANO, 2003 apud MIOTO, 2004, p.69).

A estratégia de suplência, utilizada pela enfermagem para a garantia da qualificação e manutenção da identidade profissional de seus agentes, foi criticada por Ribeiro (2009), nos seguintes termos:

No Brasil, o investimento na escolarização da classe trabalhadora sempre esteve mais presente nos discursos que na prática das políticas do setor. A suplência toma forma de estratégia da educação profissional, que sempre serviu, e continua servindo (certificação de competência), mais aos aspectos cartoriais que para a formação para o trabalho propriamente dita. Através destes processos, o trabalhador, a partir de sua experiência no trabalho, mediante a submissão a exames pontuais, adquire o título pretendido sem passar por um processo formal de ensino (RIBEIRO, 2009, p.64).

O Projeto Larga Escala (PLE) pode ser citado aqui como um dos exemplos mais concretos dessa modalidade de ensino. Implantado na década de 1980, o PLE propunha o acesso ao sistema de educação profissional formal em enfermagem de nível técnico, por meio do ensino supletivo e treinamento em serviço. A forma de educação prevista nesse projeto colocava a assistência e a prestação de serviço em saúde como um espaço educacional, cujo processo ensino-aprendizagem deveria se ajustar às características do trabalhador, ao cotidiano do trabalho e à precariedade dos estabelecimentos de saúde (PEREIRA e RAMOS, 2006). 
Em relação à conquista da habilitação profissional em técnico de enfermagem por meio do exame de "suplência profissional", Pereira e Ramos (2006) destacam que o aluno deveria garantir a educação geral regular ou supletiva, bem como comprovar que já atuava, pelo menos há dois anos, em alguma instituição de saúde.

Em termos de organização curricular para a área da saúde, a Lei $n^{\circ}$ 5.672/71 propunha que as habilitações de $2^{\circ}$ grau (ensino médio) poderiam formar técnicos (habilitação plena) ou auxiliares (habilitação parcial). O mínimo exigido em cada habilitação foi fixado pelo Parecer 45/72 do Conselho Federal de Educação, que recomendava para a formação de técnicos um mínimo de 2.900 horas, incluídas pelo menos 900 horas de conteúdo profissionalizante. Para a formação de auxiliares de enfermagem, 2.200 horas, incluídas pelo menos 300 horas de conteúdo profissionalizante (ROMANELLI, 2002).

Já na década de 1980, a sociedade civil organizada e descontente com as políticas públicas, passou a mobilizar-se com mais expressividade, mediante a participação popular contra o regime militar, exigindo liberdade, pluripartidarismo, democracia e eleições diretas para presidente da República. Pressionado pela mobilização da população, o então presidente General João Figueiredo (1979 a 1985) viu-se obrigado a acelerar o processo de democratização do País. A imprensa livrou-se da censura, criaram-se novos partidos políticos, os sindicatos conquistaram maior autonomia e greves passaram a ocorrer com mais frequência nas cidades brasileiras (BERTOLLI FILHO, 2008), marcando, assim, a participação ativa dos trabalhadores como sujeitos coletivos na busca pela redemocratização do país e na defesa por um Estado de Direito.

Nessa fase, segundo Bertolli Filho (2008), alguns avanços foram percebidos no funcionamento das políticas públicas que, sob participação popular, passaram a defender como direitos sociais de todos os brasileiros: saúde, educação, previdência e assistência social, direitos esses que passaram a ser garantidos pela Constituição Federal de 1988. Sublinha-se, nesse período, o movimento da Reforma Sanitária nas proposições para uma nova política de saúde, visando melhorias nas condições de vida da população.

No tocante à educação, a década de 1980 foi marcada por discussões em torno da recriação do Sistema Educacional Brasileiro no seu caráter democrático e público, cujo processo de negociações reivindicava a ampliação das possibilidades de acesso à educação básica, cabendo ao poder público ofertá-la gratuitamente e de forma igualitária a todos os brasileiros. Estas ideias foram deferidas pela Constituição de 1988 e, posteriormente, defendidas pela LDB $n^{\circ}$. 9.394/96. A partir da nova LDB, a educação básica passou a ser composta de três níveis: educação infantil, ensino fundamental e ensino médio.

No que tange à educação profissional, esta passou a ser estruturada nos níveis de educação básica, independente do grau de escolarização do trabalhador, sendo de nível técnico para aqueles que tivessem concluído ou estivessem cursando o ensino médio e tecnológico, que corresponde ao ensino superior (BRASIL, 1996; PEREIRA e RAMOS, 2006).

Em se tratando da educação profissional na área de enfermagem, a nova LDB, segundo Mioto (2004, p.118), passou a exigir o ensino fundamental completo, no que "condiz com as exigências para o ingresso no curso de auxiliares de enfermagem, e o ensino médio completo para o ingresso na formação do técnico de enfermagem". Tais cursos poderiam ser desenvolvidos em instituições especializadas ou no próprio ambiente de trabalho, sendo que o conhecimento adquirido na educação profissional e tecnológica, inclusive no trabalho, poderia ser objeto de avaliação, reconhecimento e certificação (BRASIL, 1996). 
No que se refere ao desenvolvimento da educação profissional de nível médio, a LDB/96, no conjunto do artigo 36, possibilita às instituições ofertarem essa modalidade de ensino da seguinte maneira:

a) articulada com o ensino médio e desenvolvida das seguintes formas:

I - Integrada: oferecida somente a quem já tenha concluído o ensino fundamental, sendo o curso planejado de modo a conduzir o aluno à habilitação profissional técnica de nível médio, na mesma instituição de ensino, efetuando-se matrícula única para cada aluno;

II - Concomitante: oferecida a quem ingresse no ensino médio ou já o esteja cursando, efetuando-se matrículas distintas para cada curso, e podendo ocorrer:

a) na mesma instituição de ensino, aproveitando-se as oportunidades educacionais disponíveis;

b) em instituições de ensino distintas, aproveitando-se as oportunidades educacionais disponíveis;

c) em instituições de ensino distintas, mediante convênios de intercomplementaridade, visando ao planejamento e ao desenvolvimento de projeto pedagógico unificado (BRASIL,1996).

b) subsequente, em cursos destinados a quem já tenha concluído o ensino médio (BRASIL, 1996). Nessa modalidade, considera-se a carga horária total do ensino médio regular ou de Educação de Jovens e Adultos (EJA), cabendo ao aluno cumprir a carga horária mínina exigida pela respectiva habilitação profissional que, no caso do Técnico de Enfermagem, é fixada em 1.200 horas, o que corrobora com a proposta das DCNs para os cursos técnicos na área da saúde, que prevê:

O ensino técnico destina-se a proporcionar habilitação profissional, mediante organização curricular própria e independente do ensino médio, conferindo titulação específica, o diploma de técnico de nível médio, para aqueles que tenham também concluído o ensino médio (BRASIL, 1999, DCNs p.10).

Ainda de acordo com as DCNs para os cursos técnicos na área da saúde, consolidadas pela Resolução 04/99 do CNE/CEB, a ênfase dada ao processo de profissionalização de agentes que irão atuar no trabalho em saúde deve se direcionar para a superação do modelo assistencial médico-hospitalar, uma vez que o processo de trabalho em saúde não se realiza apenas no espaço hospitalar, mas em diferentes espaços sociais, como a comunidade, domicílios, escolas, creches, indústrias, organizações etc.

Tais documentos entendem que a atenção e assistência à saúde abrangem todas as dimensões do ser humano: biológica, psicológica, social, espiritual e ecológica. Para a formação desses trabalhadores, os planos de cursos deverão contemplar, segundo o texto das DCNs:

Habilidades cognitivas, de abstração e análise simbólica, comunicacionais, de interrelação com clientes e demais trabalhadores; iniciativa e criatividade; capacidade de trabalhar cooperativamente em grupo e para a formação mútua no próprio local de trabalho, competência para avaliar o produto do seu trabalho e tomar medidas para melhorar a sua qualidade, e domínio de técnicas de planejamento e organização do trabalho (BRASIL, 1999, DCNs, p.07). 
Como competências gerais para os profissionais da área de saúde, a resolução $\mathrm{CNE} / \mathrm{CEB} \mathrm{N}^{\circ}$ 04/99 define:

- Identificar os determinantes e condicionantes do processo saúdedoença.

- Identificar a estrutura e organização do sistema de saúde vigente.

- Identificar funções e responsabilidades dos membros da equipe de trabalho.

- Planejar e organizar o trabalho na perspectiva do atendimento integral e de qualidade.

- Realizar trabalho em equipe, correlacionando conhecimentos de várias disciplinas ou ciências, tendo em vista o caráter interdisciplinar da área.

- Aplicar normas de biossegurança.

- Aplicar princípios e normas de higiene e saúde pessoal e ambiental.

- Interpretar e aplicar legislação referente aos direitos do usuário.

- Identificar e aplicar princípios e normas de conservação de recursos não renováveis e de preservação do meio ambiente.

- Aplicar princípios ergonômicos na realização do trabalho.

- Avaliar riscos de iatrogenias, ao executar procedimentos técnicos.

- Interpretar e aplicar normas do exercício profissional e princípios éticos que regem a conduta do profissional de saúde.

- Identificar e avaliar rotinas, protocolos de trabalho, instalações e equipamentos.

- Operar equipamentos próprios do campo de atuação, zelando pela sua manutenção.

- Registrar ocorrências e serviços prestados de acordo com exigências do campo de atuação.

- Prestar informações ao cliente, ao paciente, ao sistema de saúde e a outros profissionais sobre os serviços que tenham sido prestados.

- Orientar clientes ou pacientes a assumirem, com autonomia, a própria saúde.

- Coletar e organizar dados relativos ao campo de atuação.

- Utilizar recursos e ferramentas de informática específicos da área.

- Realizar primeiros socorros em situações de emergência.

(BRASIL, 1999, RESOLUÇÃO CNE/CEB, 04/99, p.29)

Em relação às competências específicas, a Resolução possibilita que essas sejam definidas pelas escolas, de acordo com o perfil de profissional que desejam formar. Temse, com isso, uma estrutura curricular flexível que deve se ajustar aos requisitos demandados pelos serviços regionais de saúde. Essa orientação se ajusta aos artigos $7^{\circ}$ e $8^{\circ}$ da Resolução CNE/CEB n ${ }^{\circ}$.04/99. Segundo esses artigos:

Art. $7^{\circ}$. Os perfis profissionais de conclusão de qualificação, de habilitação e de especialização profissional de nível técnico serão estabelecidos pela escola, consideradas as competências indicadas no artigo anterior.

Art. $8^{\circ}$. A organização curricular, consubstanciada no plano de curso, é prerrogativa e responsabilidade de cada escola. 
Em se tratando de carga horária para a formação de técnicos na área da saúde, passou-se a exigir "um mínimo de 2.200 horas, onde estão incluídas pelo menos 1.200 horas de conteúdo profissionalizante" (PEREIRA e RAMOS, 2006, p.35) e 633 horas para realização do estágio curricular obrigatório.

\section{Considerações Finais}

O estudo mostrou que a profissionalização da enfermagem no Brasil seguiu os preceitos da enfermagem nightingaliana. Cuja organização reflete os ideais de um trabalho de enfermagem direcionado ao cuidado de forma fragmentada e com um grau de hierarquia interna que subdivide a categoria profissional de acordo como a dinâmica processual de formação de trabalhadores a partir da lógica da divisão trabalho manual versus trabalho intelectual.

Observou-se, neste estudo, que a educação responsabiliza-se pela reprodução e manutenção dos dois tipos de trabalhadores indispensáveis a hierarquia funcional da enfermagem: aqueles que executarão o trabalho e aqueles que irão atuar no controle e planejamento do trabalho. Neste sentido, a educação e a escola atuarão para perpetuar e garantir à hegemonia e aos interesses do capital, adequando-se as condições sociais dos indivíduos. Nas palavras de Frigotto (2006, p.179):

A escola enquanto instituição que se insere no interior de uma formação social, onde as relações sociais de produção capitalista são dominantes, tende a ser utilizada como uma instância mediadora, nos diferentes níveis, dos interesses do capital [...] Numa sociedade organicamente montada sobre a discriminação e o privilégio de poucos, não há interesse por uma escolarização que nivela - em quantidade e qualidade - o acesso efetivo do saber. A desqualificação da escola, por diferentes mecanismos aqui apenas referidos, constitui-se, ao lado dos mecanismos inseridos no próprio processo produtivo, numa forma sutil e eficaz de negar o acesso aos níveis mais elevados de saber à classe trabalhadora. Esta negação, por sua vez, constitui-se numa das formas de mantê-la marginalizada das decisões que balizam o destino de sociedade.

Assim passou-se a existir na enfermagem, profissionais que passaram a exercer a gerência e a supervisão do processo saúde-doença, como no caso da enfermagem de ensino superior e aqueles que executavam os cuidados diretos aos pacientes e que eram e são destinados ao trabalho manual (auxiliares e técnicos de enfermagem), cuja educação profissional se caracteriza por noções básicas acerca das técnicas de enfermagem. Demonstrando com isso, a dualidade da educação na área da enfermagem, que ao lidar de forma desigual com a distribuição do saber, organiza-se de forma fragmentada que, em sua essência, condena os trabalhadores à alienação, encobrindo as contradições do modo de produção capitalista e o antagonismo da ordem social. No capitalismo, os conhecimentos e saberes repassados pela escola são saberes parciais que servem ao capital para garantir o processo de divisão técnica do trabalho (KUENZER, 1991).

Também foi possível perceber que a enfermagem está socialmente marcada pela divisão sexual do trabalho que a legitima como uma profissão eminentemente feminina, que se justifica no fato de que suas atividades demandam delicadeza, cuidado, bondade e submissão. 


\section{Referências bibliográficas}

BERTOLli FILHO, Claudio. História da saúde pública no Brasil. 4a . ed. São Paulo: Ática, 2008.

BRAVERMAN, Harry. Trabalho e Capital Monopolista: a degradação do trabalho no século XX. $3^{a}$ ed. Rio de Janeiro: Editora Guanabara, 1987.

DECCA, Maria Auxiliadora Guzzo de. Indústria, trabalho e cotidiano: Brasil, 1880 a 1930. São Paulo: Atual, 1991.

GERMANO, Raimunda Medeiros. Educação e Ideologia da enfermagem no Brasil. $3^{\text {a }}$ ed. São Paulo: Cortez, 1993.

LOPES, Marta Júlia Marques; LEAL, Sandra Maria Cezar. A feminização persistente na qualificação profissional da enfermagem brasileira. Cadernos Pagu (24), p.105-125, 2005.

MARQUES, Vera Regina Beltrão. A medicalização da raça: médicos, educadores e discurso eugênico. Campinas, São Paulo: Editora da UNICAMP, 1994

MIOTO, Odilamar Lopes. Formação profissional e trabalho: aspectos relativos aos técnicos de enfermagem. 170 f. Dissertação (Mestrado em Educação) Universidade Estadual de Campinas, Faculdade de Educação, Campinas, 2004.

MOREIRA, Almerinda; OGUISSO, Taka. Profissionalização da enfermagem brasileira. Rio de Janeiro: Guanabara Koogan, 2005.

OGUISSO, Taka (org.). Trajetoria histórica e legal da enfermagem. $2^{\mathrm{a}}$ ed. Barueri, São Paulo: Manole, 2007.

PEREIRA, Isabel Brasil; RAMOS, Marise Nogueira. Educação Profissional em Saúde. Rio de Janeiro: Editora Fiocruz, 2006.

PIRES, Denise. Reestruturação produtiva e trabalho em saúde no Brasil. São Paulo: Confederação nacional dos trabalhadores em seguridade social - CUT; Annablume, 1998.

RIBEIRO, Antônio César. O trabalho do enfermeiro: a relação entre o regulamento, o dito e o feito, no cotidiano hospitalar. 219 f. Tese (Doutorado em Enfermagem) Universidade Federal de São Paulo, São Paulo, 2009.

RIZZOTTO, Maria Lucia Frizon. História da Enfermagem e sua relação com a saúde pública. Goiânia: AB editora, 1999.

SAVIANI, Dermerval. O legado educacional do século XX no Brasil. $2^{\mathrm{a}}$ ed. Campinas: Autores Associados, 2006.

SOBOLL, Lis Andréa Pereira. Controle e Exploração: a produção capitalista em uma unidade hospitalar. 204 f. Dissertação (Mestrado em Administração) Universidade Federal do Paraná, Curitiba, 2003. 
STUTZ, Beatriz Lemos. Técnico em Enfermagem no Município de Uberlândia: a construção histórica de uma profissão e a primeira instituição escolar. 249 f. Tese (Doutorado em Educação) Universidade Federal de Uberlândia, Uberlândia, 2009.

WAINBERG, Sara. Experiências e vivências de auxiliares de enfermagem do sexo masculino no exercício de uma profissão majoritariamente feminina. 62 f. Dissertação (Mestrado em Psicologia Social) Universidade Federal do Rio Grande do Sul, 2004.

Notas

\footnotetext{
${ }^{1}$ Artigo elaborado a partir da dissertação de mestrado defendida em março de 2012, pelo primeiro autor, no Programa de Pós-Graduação em Educação, na Universidade Federal do Paraná, com orientação do segundo autor.

2 Bacharel em Psicologia pela Universidade Estadual do Centro-Oeste, Mestre em Educação pela Universidade Federal do Paraná, docente do colegiado de Psicologia da Faculdade Campo Real- Guarapuava -PR. E-mail: amailsonbarros@gmail.com

${ }^{3}$ Professor Adjunto do Departamento de Pedagogia da UNICENTRO, Guarapuava- PR
}

Recebido: Junho-2012

Aprovado: Agosto-2012 